\title{
PROPOSAL FOR AN INLAND SCHOOL SHIP FOR THE DANUBE REGION
}

Aim of this study is the definition of a framework for the actual realisation of a common school ship in the Danube region. After a brief outline of best practice examples for (inland navigation) school ships in Europe, the study goes on with the summary of the technical aspects of the Danube School Ship and description of the feasible vessel design (with and without lifting wheelhouse) which responds to the previous research analyses.

Keywords: Danube region, school ship, vessel design, navigation, project HINT.

\section{Introduction}

Current European documents such as the NAIADES Action Programme and the European Union Strategy for the Danube Region emphasize the importance of education in inland waterway transport sector underlining that

"A functioning education and training system is a fundamental condition for a sound and competitive labour market. The existence of education and training institutions in the sector has to be secured and their curricula adapted to current managerial, technological, linguistic and nautical need" [1].

Besides the pure educational aspects, training is also crucial for safety reasons. In this respect, practical training is of utmost importance. The effectiveness of practical training resides in the advance of professional competencies, employability of trainees and securing safe working conditions on board of ships [2].

Practical training complements theoretical knowledge acquired in class and renders training coherent and complete. It bridges the learning environment to work place through the hands-on experience. Introduction of modern learning tools such as simulators and school ships is encouraged so as they support education and training institutions to be able to educate necessary qualified personnel [3].

Practical training represents the period in which already acquired skills are consolidated, complemented and perfected and it provides the trainees with a real picture of the work place they prepare for.

Through on-board practice trainees get familiarized not only with the installations and equipment, but also with working conditions on board of the ship, they acquire appropriate general and specific professional competences and they get a glimpse of their future duties to be fulfilled according to applicable regulations and procedures [4].

On-board practical training possibilities in inland navigation are unfortunately scarce in the Danube riparian countries, which makes the development of required competencies by inland navigation crew members very difficult. The concept of a joint Danube School Ship was worked out in project HINT [4] to solve or at least reduce the lack of on-board practical training possibilities on the Danube.

\section{Best practices of existing inland navigation school ships in Europe}

There are several school ships on the Danube. But these ships are mainly not designed or retrofitted for on-board training and they are used only for 1-3 days long training trips on national waterways.

Some schools and training institutes in Western-Europe use special school ships which can be example for a joint Danube school ship. They are sailing continuously on the WesternEuropean waterways, and the students have 7-14 days long on-board trainings with them [5].

The Prinses Maxima (Fig. 1) is a motor cargo vessel with a length of $50 \mathrm{~m}$, a width of $8.0 \mathrm{~m}$ and a draught of $1.5 \mathrm{~m}$. The height of the wheelhouse is adjustable and it provides a double

\footnotetext{
* ${ }^{1}$ Martin Jurkovic, ${ }^{1}$ Andrej David1, ${ }^{2}$ Csaba Hargitai

${ }^{1}$ Department of Water Transport, Faculty of Operation and Economics of Transport and Communications, University of Zilina, Slovakia

${ }^{2}$ Department of Aeronautical, Naval Architecture and Railway Vehicles, Budapest University of Technology and Economics, Hungary

E-mail: martin.jurkovic@fpedas.uniza.sk
} 
steering post for students and trainers. The vessel provides accommodation for 24 students and 4 trainers.

The Prinses Amalia (Fig. 1) is a lighter with a length of $30.0 \mathrm{~m}$, a width of 8.0 , a draught of $1.5 \mathrm{~m}$ and a weight of 388 tons. It is a tanker lighter with all necessary equipment for loading and unloading. The bunker mast can also be used for the transhipment of cars [6].

The vessels have one teaching room each, the one of Prinses Maxima is lunchroom and recreation area as well. On board of the vessels, students learn how to handle the equipment of a modern inland vessel, how to navigate a pushed convoy and the loading and unloading of liquid cargo (coloured water) [6].
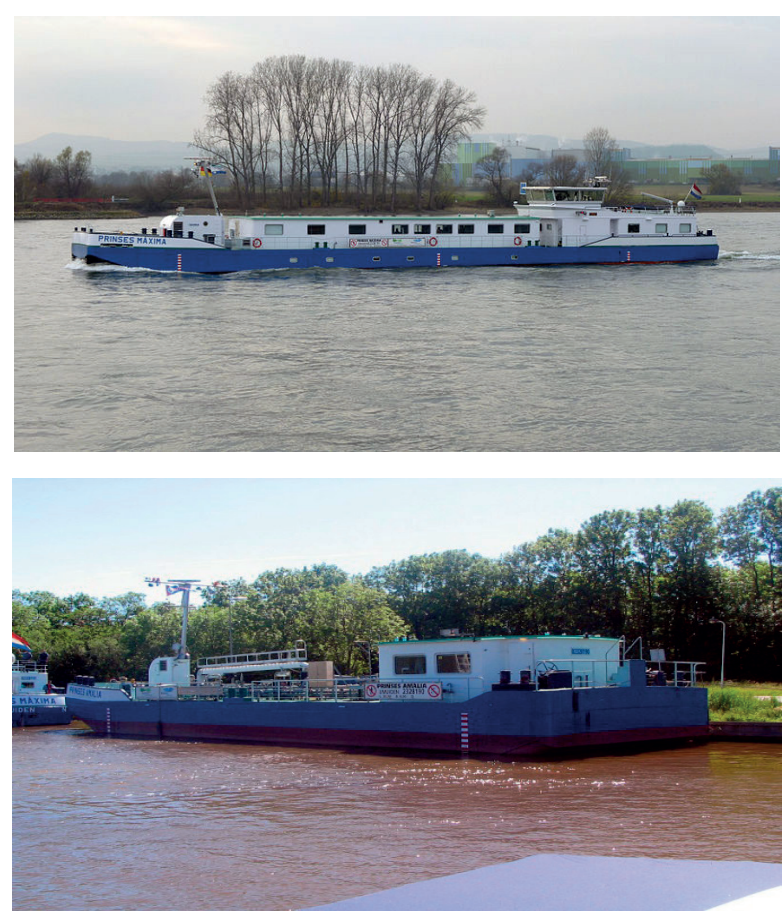

Fig. 1 The training ships Prinses Maxima and Prinses Amalia Source: Wikipedia

Operation of Themis II goes back to 10 October 2002 when the shipyard SKB, Antwerp completed the reconstruction of former vessel Romata built in 1965 (55 m x 7.20 m) and changed it into a modern school ship. The vessel received a new structure and was fitted with waterproof partitions. The bridge, lower deck, accommodation places, engines, equipment, tanks were all renewed and the new ship sailing under Belgian flag received from Bureau Veritas, on finalisation of works, the classification I 3/3 (E) N12 as passenger ship (hotel vessel) MACH (there is no classification as training ship). 17 cabins of $3 \times 3 \mathrm{~m}$ each occupy a space of $13 \times 5.5 \mathrm{~m}$. A dedicated space of $6 \times 5.5 \mathrm{~m}$ is used as lecture room [6].

\section{Vessel requirements}

The joint Danube school ship concept [4] imagines an international school ship. While she is sailing up and down along the Danube practical training courses are fulfilled with teachers and students from the whole Danube region. The trainings are 7-14 days long with 15-22 students. Beside the long trips the ship can be also used as exhibition area (while she is moored for a few days) or as a ship for practical exams of crew (e.g. for boatmaster exam two fully loaded barges have to be towed by the ship in some Danube country).

The education and training institutes can use the ship under the umbrella of an education and training institute association or they can rent her.

\section{Functional requirements}

According to the research of project HINT [4] and considering the best practice examples, the Danube School Ship should give accommodation for 20-22 students, 2 teachers and 4-6 crew members. In day cruiser operation (e.g.: sightseeing, floating exhibition, etc.) the vessel should be available for up to 50 passengers. This means that the Danube School Ship has to have accommodation for about 30 people, which also needs to be regarded at the kitchen, laundry, bathroom and storage (food, clothes, etc.) capacity. A larger room is also required for meals (breakfast, lunch, dinner) and education (classroom). The furniture of this room should be removable or changeable, because in day cruiser operation about 50 passengers have to be seated here. The education on board is planned to be organized in groups of 5-7 students [7].

\section{Machinery requirements (propulsion, auxiliary engines and bow thruster)}

The power of the main propulsion has to be determined by calculating resistance, taking the pusher option into account (two loaded barges). The minimum speed of the vessel has to be $13 \mathrm{~km} / \mathrm{h}$ in calm water, according to the Danube regulations. The ship should have double screw propulsion, because of the relative shallow draught (max. $2 \mathrm{~m}$ ) and education purposes (how to navigate with two screws). The propulsion can be the conventional diesel with a reversing and reduction gear, but diesel - electric propulsion is also possible. Using alternative fuel (LNG, CNG, fuel cell, etc.) could increase the quality of the ship, but innovative technologies would raise the costs [8].

The Danube School Ship is a special passenger vessel. Based on example school ships the required power of auxiliary engines is about $2 \times 200-250 \mathrm{~kW}$. For better manoeuvrability of the ship a bow thruster may be procured. Besides increasing navigability of the vessel, this tool also increases the navigation training quality. 


\section{Navigation requirements (navigation area, navigation profile)}

The main navigation area of the Danube School Ship is the Danube and its tributaries. Regarding the ship design, the $\mathrm{AGN}^{1}$ classification of waterways helps to define the maximum dimensions of applicable vessels. The Danube as waterway is classified from Va. to VII AGN classes. For better usability the vessel should be able to use the main tributaries of the Danube (at least in the estuary). This means that the smallest waterways where it should operate are the AGN Class IV waterways The navigation practice gives some additional limits on the measurements [9]. Because of some shallow water areas of the Danube river stretches the ship's draft should not exceed 1.6 $-1.8 \mathrm{~m}$. However the minimum height under bridges in class IV waterways is $5.25 \mathrm{~m}$, there are only 20 bridges along the Danube with less than $7 \mathrm{~m}$ clearance by $\mathrm{HNWL}^{2}$ from the total 118 bridges. This means that the Danube School Ship can have $7 \mathrm{~m}$ fix point height with an additional navigation limit by HNWL on the upper Danube section. From construction point of view the $7 \mathrm{~m}$ fix point height can be fulfilled without wheelhouse lifting, but a wheelhouse lifting system is necessary to reach $5.25 \mathrm{~m}$ fix point height [4 and 7].

The Danube School Ship needs fuel, fresh water, food and other stock storage capacities for 7 days of continuous operation. This means about $1000 \mathrm{~km}$ action radius upstream and about $3400 \mathrm{~km}$ action radius downstream. The operation profile should be the operating mode "B": 24hours of continuous movement (Table 1). This profile requires unattended machine operation [10].

Minimum required number and qualification of crew Table 1

\begin{tabular}{|l|l|}
\hline Vessel in operating mode „B“ & $\begin{array}{l}\text { Required number and } \\
\text { qualification of crew }\end{array}$ \\
\hline Self propelled vessel & $\begin{array}{l}3 \times \text { boatmaster, } 1 \times \text { deckhand, } \\
1 \times \text { machinist }\end{array}$ \\
\hline Self propelled vessel + 1 or $\mathbf{2}$ barges & $\begin{array}{l}3 \times \text { boatmaster, } 2 \times \text { deckhand, } \\
1 \times \text { machinist }\end{array}$ \\
\hline
\end{tabular}

Source: Authors

\section{New ship design}

Although the common practice for creation of a school ship is reconditioning of an old vessel, it is more advantageous to build a new vessel rather than fitting an old one to the specific educational purposes. In this case an ideal construction, among given boundary conditions, is possible and every required design parameter can be fulfilled, while the cost of ship is almost same [4 and 11].

${ }^{1}$ European Agreement of the Main Inland Waterways

\section{Main dimensions}

The Danube School Ship is a special vessel construction, because it is a cabin, cargo and pusher vessel at the same time. Considering its function, machinery and waterway AGN category No. IV., the requirements of the new Danube School Ship are $58 \mathrm{~m}$ length, $9 \mathrm{~m}$ width, $1.55 \mathrm{~m}$ of draught and $5 \mathrm{~m}$ of height (fix point height). In this case, the ship has to be equipped with a lifting wheelhouse, because the bridge clearance in waterway category No. IV. is $5.25 \mathrm{~m}$.

However, the Danube School Ship with a lifting wheelhouse (Fig. 2) can navigate under the Danube bridges at every navigable water level, but it has some disadvantages as well. The wheelhouse would be situated at the fore part of the vessel, which makes the navigation more difficult. The lifting wheelhouse has to be placed on the main deck, which makes the ship $58 \mathrm{~m}$ long. This length is more like a tug ship on the Danube than a pusher, but the navigation with two barges needs a short pusher.

In case the Danube School Ship only moves on the Danube, there are only 20 bridges with less than $7 \mathrm{~m}$ clearance under bridges during HNWL. The ship can have $6.95 \mathrm{~m}$ fix point height, a lifting wheelhouse is not necessary, and it can be placed on the top of the vessel. Without a lifting wheelhouse (Fig. 2) the Danube School Ship has $54.5 \mathrm{~m}$ length, $9 \mathrm{~m}$ breadth, $1.55 \mathrm{~m}$ of draft and $6.95 \mathrm{~m}$ of height (fix point height) [4].

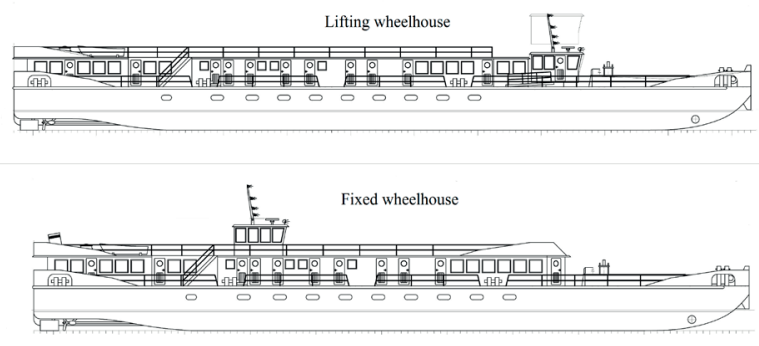

Fig. 2 New Danube School Ship with/without lifting wheelhouse Source: Danube School Ship elaborated in the framework of HINT

\section{General arrangements}

The Danube School Ship has three decks either with a lifting or a non-lifting wheelhouse. The first is the lower deck above the double bottom, which has $700 \mathrm{~mm}$ height from keel. The second is the main deck $3200 \mathrm{~mm}$ above the keel. The third is the top of the superstructure, the so called sun deck $5700 \mathrm{~mm}$ above the keel [4].

\section{Lower deck}

The lower deck (Figs. 3 and 4) is inside the hull and divided into seven main areas by watertight walls.

${ }^{2}$ High Navigable Water Level 


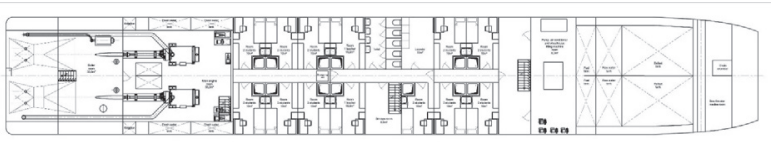

Fig. 3 Lower deck arrangement of Danube School Ship with lifting wheelhouse

Source: Danube School Ship elaborated in the framework of HINT

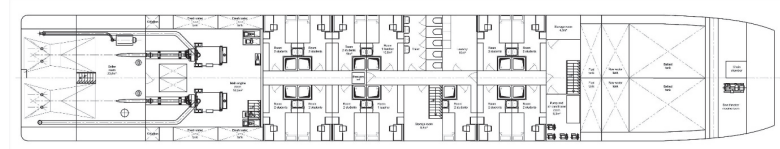

Fig. 4 Lower deck arrangement of Danube School Ship with non-lifting wheelhouse

Source: Danube School Ship elaborated in the framework of HINT

Collision spaces - The stern and bow collision spaces are because of the safety and the regulations. The rudder trunks run through the stern collision space, but the rudder machines are on the main deck in the auxiliary engine room.

Boiler room - The boiler for warm water and heating is located in the $33.8 \mathrm{~m}^{2}$ boiler room. This room is also for the warm water and Danube water hydrophores. The shaft tubes enter this space into the hull, sealed with glands. This space communicates by two watertight doors with the auxiliary engine room and the main engine room.

Main engine room - The machinery parts of propulsion (shaft, bearings, main engines, gearboxes, heat exchangers, fuel day tanks and pipe systems) are located in the main engine room, where the ship has a double side hull structure. However, the engines and other elements would not require $58.5 \mathrm{~m}^{2}$ room, this size of engine room makes it suitable for machinery maintenance trainings.

Accommodation area - The main part of the lower deck is accommodation area with 11 bedrooms for 22 students, 2 bedrooms for 2 teachers, a lavatory with 5 toilets, a laundry and a storage room.

Tank space - The fuel tanks are between the front wall of superstructure or the lifting wheelhouse and the cargo hold. Fuel tank capacity is about $40 \mathrm{~m}^{3}$. Under the bottom of cargo hold, in a $1.2 \mathrm{~m}$ high space are the raw water and ballast tanks.

Bow thruster room - The bow thruster room is located under the main deck, behind the bow collision wall. The horizontal axis, electric bow thruster, its tunnel and the necessary electrical system is installed in this space. The bow thruster room is accessible by a hatch from the main deck. [4].

\section{Main deck}

The main deck (Figs. 5 and 6) is the top of the hull. Beside the open deck areas, the superstructure, the cargo hold - and in lifting wheelhouse version the wheelhouse and its lifting machine - are situated on the main deck.

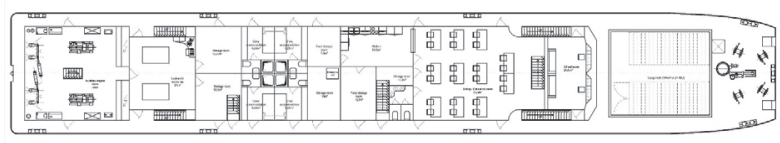

Fig. 5 Main deck arrangement of Danube School Ship with lifting wheelhouse

Source: Danube School Ship elaborated in the framework of HINT

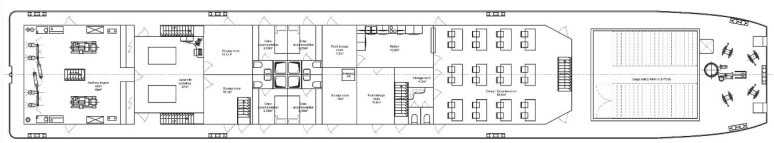

Fig. 6 Main deck arrangement of Danube School Ship with non-lifting wheelhouse

Source: Danube School Ship elaborated in the framework of HINT

Open deck areas - On the main deck there is a gangway around the superstructure. At stern the gangway is $1 \mathrm{~m}$ wide, which allows training with ropes and practising the rescue from water. All doors of superstructure open to this area and stairs to sun deck and wheelhouse start from here. The side gangways are equipped with bollards for mooring and coupling of barges [4].

Cargo hold - The cargo hold is in the fore part of the hull, behind the bow deck and before the superstructure or the wheelhouse (non-lifting or lifting wheelhouse version). The cargo hold is $7.5 \mathrm{~m}$ long, $6.2 \mathrm{~m}$ wide, and $3.1 \mathrm{~m}$ deep (with $0.9 \mathrm{~m}$ high hatch coaming). It has about $144 \mathrm{~m}^{3}$ volume, and can be loaded with general dry cargo or two standard 20 feet containers [4].

\section{Superstructure}

The main part of the main deck is the superstructure, which has the following main areas: auxiliary engine room, locksmith workshop, storage rooms, crew accommodation area, food storage rooms, kitchen and dining or education room [4].

Sun deck - Even if the Danube School Ship is built with lifting or non-lifting wheelhouse, the top of the superstructure is the sun deck. The stern anchor machine and the service boat are in the back part of the deck, the remaining area is empty and serves some board training. The sun deck can be reached by stairs from both side gangway of main deck. At the non-lifting wheelhouse version the wheelhouse is placed on top of the sun deck, but at the lifting wheelhouse version the wheelhouse is before the superstructure and the sun deck [4].

Wheelhouse - The arrangement of the wheelhouse is different, depending on lifting or non-lifting version. In both cases the area is larger than a regular wheelhouse $\left(20.8 \mathrm{~m}^{2}\right.$ or $\left.25 \mathrm{~m}^{2}\right)$, because it is equipped with a master and a slave steering posts. On the back side of the wheelhouse are seats or benches for observer trainees 
or for the examination board. The wheelhouse is designed for 9 people to stay [4].

\section{Machinery}

The propulsion of the Danube School Ship has to be designed for navigation with two loaded Danube-Europe IIb standard barges at $13 \mathrm{~km} / \mathrm{h}$. Additional requirements for the navigation training is that the ship should be a twin screw vessel, because of this propulsion the navigation with two propellers can be practised [4].

The Danube School Ship is a special passenger vessel, which has large electric energy consumption while kitchen, air conditioning, training workshops, etc. are in operation. Due to regulations and safety reasons the Danube School Ship is equipped with two auxiliary engines. Based on example school ships the power of engines should be about $2 \times 200-250 \mathrm{~kW}$ [4].

The rudder system of the Danube School Ship has to be designed for navigation with two DE IIb barges. Compared to the conventional pushers on the Danube, the Danube School Ship is longer than the average. Therefore, the vessel should be equipped with $2 \times 2$ main rudders behind the propellers, and $2 \times 2$ flanking rudders before the propellers [4].

\section{Conclusion}

The idea of a joint Danube School Ship - to at least partly solve the lack of qualified nautical personnel - was already borne some years ago. Balanced acquisition of both knowledge and practical skills is an essential prerequisite of good training resulting in a highly performing crew on board ships. On-board practical training possibilities in inland navigation are unfortunately scarce in the Danube riparian countries, which makes the development of required competencies by inland navigation crew members very difficult. Aim of the study is to establish a framework for the proposal of the harmonized Danube School Ship and to build the basis for its implementation in to the practical use within the Danube region. The document describes a feasible manner for the technical and organisational design of such a vessel in two special modifications - with or without lifting wheelhouse.

\section{References}

[1] Communication from the Commission on the Promotion of Inland Waterway Transport "Naiades", An Integrated European Action Programme for Inland Waterway Transport, Brussels, 17.1.2006, COM(2006) 6 final, p. 8.

[2] http://www.down-the-danube.com/the_danube.html. Accessed: 2014-05-01.

[3] STOPKA, O., SULGAN, M.: Recommendations for the Development of Combined Transport in Slovakia, Transport and Communications, 2012-1, Electronic J. of Faculty PEDAS, University of Zilina, pp. 346-354. ISSN 1336-7676.

[4] Danube School Ship Concept elaborated in the framework of HINT.

[5] HRASKOVA, D., BIEliKOVA, A., RYPAKOVA, M.: The Possibilities for Application of Telework in Water Transport, Our Sea: Intern. J. of Maritime Science \& Technology, 61(3-4) /2014, pp. 60-66, Dubrovnik, 2014, ISSN 0469-6255.

[6] http://de.wikipedia.org/wiki/Schul-Koppelverband_Maxima. Accessed: 2014-04-01.

[7] DAVID, A., SOSEDOVA, J.: The Danube Strategy and the Slovak Republic, ADEM 2012 - Advances in Engineering \& Management, Drobeta - Turnu Severin, December 2012, pp. 209-212, ISBN 978-606-14-0562-6.

[8] SOsedova, J., SLESINGER, M., BARIAK, M.: Telematics in Inland Navigation, Communications - Scientific Letters of the University of Zilina, vol. 12, No. 3, 2008, pp. 66-68, ISSN 1335-4205.

[9] DAVID, A., SLESINGER, J., JURKOVIC, M., HARGITAI, C., GYORGY, D., SIMONGATI, G.: Danube Navigation Requirements and Concept, Zilina : Budapest, September 2014.

[10] JURKOVIC, M., DAVID, A.: Technological and Educational Requirements for Inland Navigation Simulator in the Danube Region. Our sea: Intern. J. of Maritime Science \& Technology, vol. 62, No. 1, 2015, pp. 13-19, ISSN 0469-6255.

[11] KALINA, T., MIKUSOVA, M.: Simulation of Ship Management in Preparation of Professionals for Inland Navigation, Computer systems aided science, industry and transport - TRANSCOMP 2011, 15 $5^{\text {th }}$ intern. conference, Zakopane, December 2011, pp. 205, ISBN 978-83-7789-654-7. 